\title{
Bringing the Faithful Back In: The Influence of Catholics and White Evangelicals on Polarization in State Abortion Politics
}

\author{
Brian Robert Calfano
}

I use two maximum likelihood models to assess whether the density of Roman Catholics and white evangelicals in state legislative districts significantly increases the likelihood that state House representatives hold the "pro-life" position on abortion. As hypothesized, the relative district density of both Catholic parishes and white evangelical adherents is found to be a significant "pro-life" influence. These are provocative findings. They suggest that not only is officeholder polarization the product of machinations by political elites (Fiorina et al. 2006), but that interested publics representing essentially non-political institutions and constituent blocs also contribute to such polarization, at least in regard to state abortion politics.

\section{The Politics of Polarization}

According to Fiorina et al.'s (2006) thesis, political officeholders pursue polarization on culture issues, of which abortion is the most notable example. Intriguingly, legislative officeholders assume polarizing positions even as most of their constituents are largely unsupportive of this approach. Why this disconnect? The authors, with help from the extant literature (Edelman 1964; Mayhew 1974; Fenno 1978; Arnold 1990), link officeholder behavioral motivation, in part, to the approbation and financial support they receive from party activists, interest groups, and strongly partisan voters. These interested, issue-based groups and elites are the progenitors of polarized policy preferences. The legislative officeholder, whose re-election is significantly dependent on interest group support, then adopts, or at least publicly supports, these preferences.

This process makes political elite polarization a cyclical and synergistic enterprise: officeholders, party activists, and partisan constituents cooperate to shape the political landscape in an absolutist image. In turn, a simplified political narrative is created that helps preserve officeholder and elite hegemony (Carmines and Stimson 1980; Dodd 1993; Oldmixon 2005). And, in the end, the American voter is left to select between the lesser of two polarizing candidates, neither of which adequately represents the electorate's true preferences on cultural concerns.

Special thanks to Elizabeth Anne Oldmixon and Corey Ditslear for their helpful comments on earlier versions of this manuscript.

BRIAN CALFANO is assistant professor of political science at Texas A\&M University.

The American Review of Politics, Vol. 27, Summer, 2006: 129-148

(C)2006 The American Review of Politics 
However, despite this theory's elegance, a rather substantial puzzle exists. Since legislative officeholders remain in power by virtue of electoral support, any theory explaining officeholder behavior must be particularly sensitive to constituent political influences, whether these constituents are closely linked with the political elite class or not. Such sensitivity is lacking in the most recent literature that casts political polarization as a phenomenon created by, and for, political elites (Fiorina et al. 2006). Thus, I consider whether constituent groups and elites that are organized on a basis other than politics, but that are relatively well-known for holding polarized abortion preferences, also exercise influence over legislative officeholders. Empirical progress on this puzzle might bring into sharper relief the actual role that certain constituent blocs, which are not part of the political activist and elite core, play in either animating or buffering polarization on abortion.

As it regards constituent groups, white evangelicals and Roman Catholics rank as the two institutionally non-political groups that are the most likely to hold polarizing "pro-life" views. Critical from a Mayhewian (1974) standpoint, both represent large legislative constituencies in most states. Since legislative districts at the sub-national level provide an opportunity to assess constituent influence in relatively small electoral contexts, I pursue a comparative state-level study of Roman Catholic and white evangelical influence on the abortion position of members in six state Houses of Representatives.

Though an important stream of research has focused on the impact of the New Christian Right in state politics, a movement comprised mostly of white evangelicals, Roman Catholics have been largely overlooked (Green 2000; Rozell and Wilcox 1995; Green, Rozell, and Wilcox 2003). Hence, including Roman Catholics in a state-level analysis of religiously affiliated constituents, and their potential political influence, represents an important advance in the literature.

As suggested, studies of local religious communities, their elites, and their role in the political milieu, have been plentiful. For example, Guth et al. (1997), Olson (2000), and Smidt (2004) conducted comprehensive studies of clergy political behavior. All discovered that clergy political activism is a nuanced and theologically informed matter for most ecclesiastical elites. From a parishioner-centered standpoint, Wald, Owen, and Hill (1988) established that churches are a key transmission point for communicant political values. And, in the legislative theater, Green and Guth (1991) found that a congressional district's denominational composition is a significant influence on the voting behavior of congressional officeholders.

Thus, while Roman Catholic and white evangelical communities are considered inherently non-political from the standpoint of their religious identity, the literature indicates that they, nonetheless, have been galvanizing 
forces for political activism (Wald 2003). This is especially true for white evangelicals, who have been shown to have a high level of Republican Party identification and support for GOP candidates and agendas (Kellstedt and Green 1993).

Given the close connection between these religious communities and the political domain, one might suggest that these communities are actually part of the political elite class. However, this characterization is strongly rejected. Religious communities are, first and foremost, concerned with mediating between humanity and the metaphysical. Though political activism might be important for some of the religiously affiliated, such behavior remains a secondary concern to the decidedly metaphysical rituals, beliefs, and experiences that constitute a faith community's essential fabric (Zeitlin 2003).

The same goes for religious elites. Unlike for political interest group and party leaders, the institutional and professional raison d' etre of religious elites is prima facially non-political, even as there may be a political sub-component to their behavior (Olson et al. 2005). ${ }^{1}$ Thus, religious communities should be seen as possessing specific political resources. They should not, however, be considered part of the cadre of full-time partisans and political elites.

\section{Discerning Political Influence among the Faithful}

I suggest that Roman Catholic and white evangelical communities can influence state officeholder abortion positions by virtue of two important organizational resources: (1) their existing "pro-life" preference reputations and (2) the inherent institutional and constituent-defining boundaries that local parishes and congregations provide (Byrnes 1991, 1993; Rozell and Wilcox 1995). These are critical political resources. Both provide Catholics and white evangelicals the means to be viewed by state officeholders as defined constituent blocs with a reputation for salient "pro-life" preferences. This, regardless of whether or not individual houses of worship and communicants engage in specific forms of political activism.

Importantly, whatever similarities Catholics and white evangelicals have, certain differences also likely exist. One critical example is the level of abortion preference homogeneity among parishioners in the two communities. That a large majority of white evangelicals hold strong "pro-life" preferences is well documented (Fowler, Hertzke, and Olson 1999; The Pew Forum on Religion and Public Life 2005).

And, while it is also true that Roman Catholicism has been a launching pad for "pro-life" political activism, there is a critical difference between it and evangelicalism on this point. As Byrnes (1991; 1993) notes, "pro-life" 


\section{2 | Brian Robert Calfano}

sentiments are most strongly held by Catholic elites, including priests (O'Connor 1996; Jelen 2004). The Catholic laity, in contrast, is far less supportive of the "pro-life" view, especially the millions who do not attend Mass on a weekly basis (The Pew Forum on Religion and Public Life 2005; Wald 2003; Kelley, Evans, and Headey 1993; Charles 1999; Castelli 1987; Leege and Welch 1989).

These realities suggest that white evangelicals have a comparative advantage over Catholics in generating and exercising political influence on abortion. However, the Catholic Church also possesses a unique political resource - its strong institutional linkage (Jelen 2003; McMullen 1994; Burns 1992). Specifically the Catholic Church exercises political influence through its institutional connectivity, which helps compensate for its lack of parishioner preference homogeneity on abortion. ${ }^{2}$ While most white evangelical congregations can be expected to support the "pro-life" position, their lack of institutional and denominational linkage means that there is likely far less coordination and continuity between them.

Despite their differences, the mechanism supporting the political influence of both faith communities is relatively the same - their ability to signal their "pro-life" preferences to state House members. Such signaling is critical because officeholders, despite their close relationship with political interests and elites, are also eager to claim credit from important electoral constituencies, as their re-election depends on it. As such, officeholders are likely motivated to satisfy Catholic and white evangelical abortion policy concerns in addition to the other sets of interests, both elite and partisanbased, that they must address (Mayhew 1974; Fenno 1978; McCarthy and Zald 1978).

Importantly, I make no claim concerning specific instances of political activism by local parishes and congregations. Conducting such an analysis requires the Herculean task of surveying the affairs of tens of thousands of houses of worship, and is, quite obviously, prohibitive. It is granted that some churches and parishes may pursue more ostensible political activity than others. The same goes for individual members and elites in these religious communities.

For federal tax reasons, however, it is also assumed that no parish or congregation will ever try to take on the kind of partisan behavior that is found among political interest groups and party-level elites. Given these assumptions, the influence of Catholic and white evangelical communities is operationalized by their relative district densities. This approach allows the relative institutional and constituent community size of both groups to speak for themselves statistically, without overstating the reasons for influence that each may have on the abortion position of state House members. 
Based on the discussion above, I hypothesize that as the density of white evangelical adherents in a state House district increases, so does the likelihood that the House member holds the "pro-life" position. The density of the largely fragmented white evangelical congregations will have no effect on House member position. I further hypothesize that as the density of Roman Catholic parishes in a state House district increases, so does the likelihood that the House member holds the "pro-life" position. The density of the less politically homogenous Roman Catholic adherents will have no effect on House member position.

\section{Modeling Political Influence}

I employ a dichotomous dependent variable that measures state House member abortion position as either "pro-life" (coded 1) or "pro-choice" (coded 0). ${ }^{3}$ Given Fiorina et al.'s (2006) finding of officeholder polarization, such should especially be true regarding abortion. This justifies the dichotomous measure. ${ }^{4}$ As no existing data taps these specific indicators, I have created an original data set to do so.

Four variables capture the density of the Roman Catholics and white evangelicals in state House districts. The first two measure the density of both groups' institutional district presence. Summing the number of Catholic parishes and white evangelical congregations in each House district, and then dividing these by a district's total houses of worship, creates the first two density measures. The third and fourth measures are calculated by summing the number of Catholic or white evangelical district adherents, and then dividing these by the total population in each House district. The result is the district density of Catholic and evangelical adherents. I aggregated data for all four religious density variables by following the coding scheme established in the 2000 edition of the Religious Congregation and Membership Survey (RCMS) published by the Glenmary Research Center (Jones et al. 2002).

The RCMS data are broken down by county, which presents a challenge for analyzing multi-county legislative districts. For these districts, I used the proportion of votes cast in the 2002-2003 legislative election cycles to generate the proportion of voters from each county in state House elections. I then assigned this proportional measurement to the adherent and parish/congregation density variables for each county in the multi-county districts. (See the appendix for additional discussion of the RCMS data and its application to state House districts.)

Most of the control variables are based on a modified version of those used by Medoff (2002). They, and their hypothesized effects on a House member's "pro-life" abortion position, are urban areas (Fischer 1995, 
negative), officeholder Republican Party identification (Aldrich 1995, positive), district per capita income (Hall and Ferree 1986, negative), percentage of district residents with an undergraduate education (Hall and Ferree 1986, negative), district proportion of African-American and Hispanic residents (negative), and being a female House member (Hansen 1993, negative).

I also incorporated two additional controls. The first is Erikson, Wright, and McIver's (1993) measure of state ideology. This is used to account for the possibility that House member abortion position is the result of general liberal or conservative tendencies in state electorates, not the relative density of Catholics and white evangelical communities in state legislative districts (Arceneaux 2002).

The second is a measure of the existing abortion restrictions in each state. This controls for the influence that policy legacies might have by shaping and constraining the issue space in which officeholders operate. Following Wetstein and Albritton (1995), I constructed this measure via NARAL's 2001 report of state abortion policies. ${ }^{5}$ I then ran correlation tests on all control variables. No controls correlated higher than 0.47 .

Data for the education, race/ethnicity, urban centers, and district income controls were culled and coded from 2000 U. S. Census data, and were apportioned in the same manner as the parishes for multi-county House districts described above. State legislative databases furnished measurement of representative party identification and sex. With regard to the evangelical Protestant congregation count, every effort was made to exclude AfricanAmerican congregations and adherents (Kellstedt and Green 1993). I made this decision based on Finke and Scheitle's (2005) research that shows African-American Christians are widely underrepresented in RCMS data.

I selected the six states in this analysis because they are in regions where conservative religious communities are not usually expected to wield considerable political influence. Given the widespread Republican realignment in the south, one might expect a strong causal relationship between "pro-life" religious communities and "pro-life" legislative behavior there (Glaser 1996).

Testing for such relationships in other regions of the country, however, opens up a new research path that only strengthens the significance of whatever causal patterns are discovered. On these criteria, a bloc of upper midwestern and northeastern states are examined-Massachusetts, Michigan, New Jersey, New York, Ohio, and Pennsylvania.

Between these six states, there are 802 single-member House districts. I obtained abortion position data from abortion interest groups for all but 23 members, for a total $n$ of 779 , which covers just over $97 \%$ of the state House members. These missing members are spread rather evenly between the six states. ${ }^{6}$ Model one, the results of which are reported in table one, was run using robust standard errors to account for heteroskedasticity. 
Table 1. Probit Coefficients for Catholic and White Evangelical Influence on Representative Abortion Position (Combined State Model)

\begin{tabular}{|c|c|c|c|}
\hline & $\begin{array}{l}\text { Combined Model } \\
\quad(\mathrm{n}=779)\end{array}$ & $\begin{array}{l}\text { Predicted } \\
(+1 S D\end{array}$ & $\begin{array}{l}\text { d Probabilities } \\
-1 \mathrm{SD})\end{array}$ \\
\hline Catholic Parishes & $\begin{array}{l}.031^{* *} \\
(.012)\end{array}$ & .57 & $.40=.17$ \\
\hline Catholic Adherents & $\begin{array}{l}-.001 \\
(.005)\end{array}$ & & \\
\hline Evangelical Congregations & $\begin{array}{l}.006 \\
(.008)\end{array}$ & & \\
\hline Evangelical Adherents & $\begin{array}{l}.010^{*} \\
(.005)\end{array}$ & .52 & $.46=.06$ \\
\hline Urban & $\begin{array}{l}-.026 \\
(.144)\end{array}$ & & \\
\hline Race & $\begin{array}{l}-.024 * * * \\
(.004)\end{array}$ & .32 & $.66=.34$ \\
\hline Rep. Party ID & $\begin{array}{l}1.18^{* * *} \\
(.134)\end{array}$ & .76 & $.31=.45$ \\
\hline Education & $\begin{array}{l}-.304^{*} \\
(.145)\end{array}$ & .43 & $.55=.12$ \\
\hline Income & $\begin{array}{l}.012 \\
(.906)\end{array}$ & & \\
\hline Female Member & $\begin{array}{l}-.575 * * * \\
(.141)\end{array}$ & .32 & $.54=.22$ \\
\hline State Ideology & $\begin{array}{l}-.019 \\
(.062)\end{array}$ & & \\
\hline State Abortion Restrictions & $\begin{array}{l}.014 * * * \\
(.003)\end{array}$ & .65 & $.33=.32$ \\
\hline Constant & $\begin{array}{l}-1.51 \\
(.521)\end{array}$ & & \\
\hline Wald $\mathrm{Chi}^{2}$ & 241.71 & & \\
\hline Log-Likelihood & -336.72 & & \\
\hline
\end{tabular}




\section{Polarizing}

Model one's results demonstrate the influence that religiously based constituent blocs have on House member abortion position, even as various political elite and demographic measures also show strong influence. Specifically, the district densities of both the white evangelical adherents and Roman Catholic parishes are found to have a significant influence on the "pro-life" position of state House members.

Importantly, and as predicted, neither the density of Catholic adherents, nor that of white evangelical congregations, is found to have a significant "pro-life" influence. These results suggest that Roman Catholics and white evangelicals do possess distinct comparative advantages that make them effective players on the state political scene. It also makes them unique contributors to issue polarization on abortion.

Since maximum likelihood coefficients cannot be interpreted directly, it is necessary to calculate predicted probability measurements for each significant independent variable. To do so, two probability figures are calculated for each significant variable. The first is at one standard deviation above the variable's mean, the second at a standard deviation below. The difference between the two standard deviations is the predicted probability value for that significant variable.

Results show that an increase in the density of Catholic parishes in each state House district increases the probability that a House member holds the "pro-life" position by .17. Meanwhile, an increase in the district density of white evangelical adherents increases the probability that a state House member holds the "pro-life" position by .06. These findings are strong evidence that justify bringing broad constituent groups back into the analysis of the culture wars, and the political polarization that drives them.

As mentioned above, model one also shows that decidedly political factors hold sway on a House member's decisional calculus. Most notable is the strong significance of member party identification. Using Democrats at the baseline, member identification as Republican increases the likelihood that $\mathrm{s} /$ he holds the "pro-life" position by .45 . This is clearly the strongest influence on officeholder position in the entire model.

Fiorina et al. (2006) would suggest that the variable's robustness is based largely on the dependent relationship that party organizations have with issue-oriented interest groups and elites. To the extent that parties have come to depend on financial and organizational support from these groups, and to the extent that the interest groups expect party elites to reciprocate by adopting polarizing positions on cultural concerns, it is understandable why parties would exert such strong pressure on their officeholders' position on cultural issues. 
Also of note is the influence that the existing abortion policy context has on House member position. Model one finds that an increase in existing "pro-life" abortion policies increases the likelihood that a member holds the "pro-life" position by .32. This suggests that, at least in state politics, polarizing cultural policies have a significant, self-enforcing component that shapes the future position that officeholders take. This explanation is strengthened by the fact that the NARAL data measure state-level abortion restrictions as of 2000, while House member data are drawn from the 2002-2003 legislative session.

Finally, it is striking, but not necessarily surprising, that being a female House member cuts through as a strong "pro-choice" influence. If being a woman increases the probability that the House member holds the "prochoice" position by .22 , then a credible case for a gender gap between male and female political elites can be made. Not surprisingly, this gender gap is filtered through a decidedly partisan lens. Crosstabulations show that 50 of the 158 female officeholders in the six states are Republican, and 45 of these are "pro-life." In contrast, no female Democrat officeholders are "pro-life." Largely in line with congressional trends, the most frequent "pro-life" officeholders are Republican men.

In addition to the confirmed comparative political advantages of Roman Catholics and white evangelicals, model one shows the influences on House member abortion position are varied across an array of constituent, elite, and even personal domains (Oldmixon 2005). This variety further necessitates expansion of the relevant constituent-based actors who considered part of the causal story in the polarization of cultural politics.

\section{Abortion, Church, and the States}

Since this is a study of House member abortion position across six states, it is worthwhile to rerun model one using individual state controls. Ohio, which represents the midpoint in terms of the size of its general population and Roman Catholic and white evangelical communities, serves as the baseline in this second, state-controlled model. In checking for multicollinearity, it was discovered that the district income variable correlates at .80 or higher for three of the states (New York, New Jersey, and Massachusetts). As such, and because the income variable was not significant in model one, district income is dropped. Results are reported in table two.

The effects in the state-controlled model are largely similar to those found in the first, but with a notable difference: the predicted probability values for the density of Catholic parishes and white evangelical adherents increase by .01 and .02 respectively. This adds confirmation to the evidence from model one: these non-political constituent groups have influence on House member abortion position by virtue of their relative district densities. 
138 | Brian Robert Calfano

Table 2. Probit Coefficients for Catholic and White Evangelical Influence on Representative Abortion Position (Individual State Model)

\begin{tabular}{|c|c|c|c|}
\hline & $\begin{array}{l}\text { State Model } \\
\quad(\mathrm{n}=779)\end{array}$ & $\begin{array}{c}\text { Predicte } \\
(+1 \text { SD }\end{array}$ & $\begin{array}{l}\text { d Probabilities } \\
-1 \text { SD) }\end{array}$ \\
\hline Catholic Parishes & $\begin{array}{l}.035^{* *} \\
(.012)\end{array}$ & .58 & $.40=.18$ \\
\hline Catholic Adherents & $\begin{array}{l}-.002 \\
(.006)\end{array}$ & & \\
\hline Evangelical Congregations & $\begin{array}{l}.010 \\
(.008)\end{array}$ & & \\
\hline Evangelical Adherents & $\begin{array}{l}.010^{*} \\
(.005)\end{array}$ & .53 & $.45=.08$ \\
\hline Urban & $\begin{array}{l}-.076 \\
(.159)\end{array}$ & & \\
\hline Race & $\begin{array}{l}-.027^{* * * *} \\
(.004)\end{array}$ & .32 & $.67=.35$ \\
\hline Rep. Party ID & $\begin{array}{l}1.18^{* * *} \\
(.136)\end{array}$ & .76 & $.31=.45$ \\
\hline Education & $\begin{array}{l}-.261 \\
(.140)\end{array}$ & & \\
\hline Female Member & $\begin{array}{l}-.581 * * * \\
(.141)\end{array}$ & .33 & $.54=.21$ \\
\hline State Ideology & $\begin{array}{l}-.010 \\
(.015)\end{array}$ & & \\
\hline State Abortion Restrictions & $\begin{array}{l}.012^{* *} \\
(.003)\end{array}$ & .62 & $.36=.26$ \\
\hline Pennsylvania & $\begin{array}{l}.519^{*} \\
(.239)\end{array}$ & .63 & $.43=.20$ \\
\hline Massachusetts & $\begin{array}{l}-.345 \\
(.301)\end{array}$ & & \\
\hline New York & $\begin{array}{l}-.406 \\
(.306)\end{array}$ & & \\
\hline New Jersey & $\begin{array}{l}-.512 \\
(.265)\end{array}$ & & \\
\hline Michigan & $\begin{array}{l}.351 \\
(.247)\end{array}$ & & \\
\hline Constant & $\begin{array}{c}-1.51 \\
(.521)\end{array}$ & & \\
\hline Wald $\mathrm{Chi}^{2}$ & 245.68 & & \\
\hline Log-Likelihood & -335.03 & & \\
\hline
\end{tabular}


All remaining control variables, with the exception of district education, which was the least robust of all the significant controls in model one, retain their significance in the second model. Party identification continues to exact a strong influence on member abortion position. The same is true of the existing abortion restriction variable. The female House member measure also retains its strong "pro-choice" influence with state controls included.

Adding the individual state controls helps to assess whether there is a specific state-level influence on member abortion position over and above what model one's specification captures. This approach paid off, as Pennsylvania is found to significantly affect House member "pro-life" position. Predicted probabilities in table two show that holding office in the Pennsylvania General Assembly increases the likelihood that a House member holds the "pro-life" position by .20 .

All the remaining states, with the exception of Michigan, are signed negative. This suggests that officeholders encounter a "pro-choice" influence by virtue of their service in Massachusetts, New York, and New Jersey. That these three northeastern states, all with relatively liberal state ideologies, and few existing abortion restrictions, exercise a "pro-choice" influence on member position is not surprising. What is intriguing, however, is Pennsylvania's significant "pro-life" influence.

The Keystone State's mixed political environment certainly makes this an intriguing finding. Though it has Republican majorities in both chambers of its state legislature, it also has a fairly popular Democratic governor. Concomitantly, it has gone for the Democratic presidential candidate in every election since 1992, despite a significant effort by George W. Bush to carry the commonwealth in 2004.

Ironically, despite its general predisposition toward supporting the Democratic Party in presidential elections, Pennsylvania also registers a high level of restrictive abortion policies. Its NARAL score of 84 is higher than Ohio's 67 and Michigan's 81 (in contrast, the three northeastern states have scores ranging from 9 in New York to 41 in Massachusetts). Indeed, according to NARAL, Pennsylvania consistently ranks just behind Louisiana as the most restrictive state in which to procure abortion services (2001).

Might it be that Pennsylvania's unique effect on House member abortion position is caused largely by a higher-than-normal influence from the Catholic and white evangelical densities in its state House districts? In order to assess this possibility, the state control model was rerun with interaction terms between the Pennsylvania control and the four Catholic and white evangelical variables. Interestingly, these interactions do not account for Pennsylvania's difference from the other states (results not shown). Not only are the interactions not significant, there are no changes in the predicted probability values for the significant variables in the state controlled model. 
These non-results are critical in that they show that Catholic and white evangelical political influence across the six states is not simply the product of an above average level of influence these religious communities enjoy in Pennsylvania. Hence, an explanation for the Pennsylvania anomaly will have to come from elsewhere. This elsewhere might be found in a Keystone exception to the most significant variable in both models-House member party identification.

It is noteworthy that the 2002-2003 session of the Pennsylvania General Assembly contained not only a majority of "pro-life" Republicans, but also a simple majority of Democrats with the same position $(52 \%$ of the session's 94 Democratic members were "pro-life"). This is significant because member abortion position in the remaining states lines up largely along conventional party lines, with 80 to $90 \%$ of party members aligning according to national party trends. Hence, the nexus between party organizations and their close interest group allies, though still a strong, polarizing combination in most states, cannot be considered a general given condition in state politics.

The obvious resulting question is whether Pennsylvania contradicts Fiorina et al.'s (2006) characterization of cultural polarization as a political elite-led phenomenon. The answer is likely no, at least in terms of the preference officeholders and their interest group allies have for zero sum politics in the cultural domain. What does require qualification, however, is the assumption that officeholder and party cleavages will necessarily coincide as strongly at the state level as they do at the national.

Unfortunately, without thickly descriptive data documenting the dynamics at play in Keystone State politics, and the remaining states for that matter, it is not possible to say more concerning the decidedly state-level dynamics of political polarization on abortion. As such, additional scholarly attention is certainly in order. Future research might concentrate on any systematic differences between Catholic and evangelical elite behavior in state legislative districts, and the extent to which such behavioral differences translate into differences in political influence. Research should also focus on the role that geographic region might play in shaping state policy formation. After all, and as Fiorina et al. (2006) note, many red and blue states actually reflect purple tendencies once state-level dynamics are taken into account!

\section{Conclusions}

These results necessitate acknowledgement that while political elite polarization is driven by non-constituent factors, mass constituencies that are known for specific preferences on cultural issues also contribute to the polarization process, at least on abortion. 
By focusing on what might be termed minimalist measures of statelevel constituent blocs, I have widened the scope of factors considered influential in the politics of cultural polarization. I selected the Roman Catholic and white evangelical communities for examination here because they are both, institutionally speaking, non-political in their constitution. They are separate from the cadre of full-time political interest and issue groups that Fiorina et al. (2006) suggest compels officeholders to stake polarizing positions on abortion and other cultural concerns. Although both religious communities come to their political influence through somewhat different comparative advantages, that these non-political groups even enjoy such influence simply by virtue of their relative density in state House districts is a noteworthy discovery.

Of course, Fiorina et al. (2006) make mention of the influence that religiously motivated political elites and partisans enjoy in state politics (168-169). What sets these results apart from the authors' expectation, however, is that the Catholic and white evangelical district densities used here systematically concentrate on the two religious communities as state-level constituent blocs, not party-level and interest group elites operating in national politics. At the state level, these religious-based blocs possess significant influence that contributes to officeholder polarization on abortion, even after controlling for district demographics, state ideology, state abortion policy context, and House member party identification.

This suggests that Fiorina et al.'s (2006) broad characterization of the electoral masses as largely non-polarizing might be in need of revision. Though the authors cite a multitude of opinion data to corroborate their claim that even a majority of white evangelicals are middle-of-the road on abortion policies, their data measure electoral dimensions that are not precisely tailored to assess cause and effect in the state legislative context. Hence, the models here return findings that remain valid and plausible in the precise context of the state House electoral district.

Given these results, an obvious question concerns the political influence of Catholics and white evangelicals in the remaining forty-four states. Recall that the major justification for selecting these six is their non-southern location. Assuming that the white evangelical presence in the south increases in terms of district density, it is likely that significant evangelical constituent influence exists in that region as well.

Of course, less certain is the broader influence of Catholic parishes, although given the Church's increased presence in the southwest, Catholic influence might not be confined to the northeast and Midwest alone. Similarly interesting questions abound for religious constituent influence on West coast officeholders, all of whom serve in arguably the power base of cultural liberalism. These findings can also be justifiably expanded to include other 
polarizing cultural issues, gay marriage and euthanasia being two notable examples.

Yet even without the benefit of additional studies, the logic of the constituent-centered theories, and the influence that Catholic parishes and white evangelical adherents are found to have, suggest that religious constituent influence should exist in almost any state legislative context. This is because officeholders are likely to rely on the prevalent heuristic that both white evangelicals and the Catholic Church possess strong "pro-life" preferences, and will work to both punish and reward officeholders in relation to those preferences. This may occur even if the actual abortion policy preferences of certain religious adherents are more nuanced than the overall reputation of their religious communities would suggest.

Perhaps officeholder reliance on this general heuristic will change over time. This, especially if new opinion data in state electorates, utilizing consistent questions and scales to measure respondent abortion preferences, reflects Fiorina et al's (2006) thesis of mass-level non-polarization. Until this occurs, however, it is likely that state House members would rather be safe than sorry. Being safe means assuming strong "pro-life" preferences for these traditionally "pro-life" constituent blocs, especially when the relative district density of a "pro-life" constituency is high.

Obviously, the constituent-based assessment furthered here stands in tension with the view that political elites are the true culprits of political polarization. However, these are not regrettable differences. After all, understanding the causes of legislator behavior has long been a growth industry that represents several, often competing, takes on why officeholders behave as they do. With these results implicating non-political religious communities in the business of state-level, officeholder influence, the future is made brighter for gaining greater insight into the politics of cultural polarization, and the role of both political and non-political players in this process.

\section{APPENDIX}

As with any large data set, there are measurement problems to address. As Finke and Scheitle (2005) point out, African American denominations are vastly undercounted in the RCMS. Concomitantly, many congregations that are not associated with a denomination, including white evangelical churches, and which the RCMS does not pick up in its unaffiliated category, are also missing. This has the effect of inflating the size of the secular or non-religious community in each legislative district. Given their vast underrepresentation, the African-American denominations are excluded from the analysis entirely. Circumventing the inflation of the secular/non-religious community in each district is much more difficult given its pervasiveness throughout the RCMS. As such, the reader should be aware of this limitation. 
APPENDIX (continued)

One of the great advantages of studying state House districts is that a population control is already built into the model. In some cases, however, House district boundaries do not conform exactly to county lines, which is the unit the RCMS uses to subdivide its state-level data. In some cases, state legislatures use multiple counties, or sections of those counties, to create a state House district. In order to estimate the proportion of each county in the multi-county districts, the average proportion of voters from each multidistrict county who voted in the previous three House elections in each state was calculated (based on public election returns made available by each state's Office of the Secretary of State). Using this multiple election average controlled for any aberrations in voter turnout in a single election.

Each county's vote proportion in a multi-county district was converted to a percentage, with the combined portions of all the counties in multi-county districts summing close to 100 (accounting for rounding error). Each county's demographic and religious parishioner and parish/congregation values were then multiplied by the percentage created from the multi-county procedure. Each county's percentage was then summed to create a composite value for each appropriate variable in the multi-county districts.

\section{NOTES}

${ }^{1}$ The exception would be those officeholders and political elites who also have a strong identity and involvement in religious communities. This study forgoes examination of this small class of elites for various reasons, including a lack of data concerning their religious practices and beliefs.

${ }^{2}$ The argument is not that Catholic adherents are unable to function as a "pro-life" influence in the same way as their white evangelical brethren. Indeed, since a sizeable percentage of Catholic adherents claim to hold "pro-life" views, one should expect a similar influence to exist in theory. However, given that the aggregate count of Catholic adherents in the general population cannot be broken down into "pro-life" and "prochoice" camps, and given that Mass attendance data, which would help construct such a measurement, is largely unavailable or cannot be disaggregated for state legislative studies, it is unrealistic to expect that Catholic political influence is animated in the same manner as it is hypothesized as being for white evangelicals.

${ }^{3}$ Abortion interest groups providing data for the dependent variable include: the NARAL organizations in all six states; the Pennsylvania Pro-life Federation; Michigan and New Jersey Right to Life; the Massachusetts Citizens for Life; the New York State Right to Life Committee; and the Ohio Right to Life Society. Each group was contacted to provide data for the 2001-2003 legislative sessions. Given that the U. S. Census and parish/congregational data are collected at decentennial intervals, it is appropriate to examine legislative sessions as close to the collection of the census data as possible so as to capitalize on the higher level of accuracy for these years. Importantly, interest groupbased measures of legislative behavior have been criticized in the literature (see especially Jackson and Kingdon 1992). Indeed, explaining votes with votes is an undesirable approach if other options are available. Alternative measures, such as Ansolabehere, Snyder, and Stewart's (2001) survey based approach, have proven effective. However, using speeches and/or surveys to ascertain the abortion position of a group of state 


\section{4 | Brian Robert Calfano}

legislators that outnumber members of the U.S. House of Representatives by almost 2 to 1 is unrealistic. Since the interest group-based categorization employed here provides a reasonably useful position measurement across the widest range of state House members, its use is the most appropriate alternative.

${ }^{4} \mathrm{~A}$ good portion of the abortion politics literature captures abortion position as either an ordinal or ratio-level variable. This is mainly because these works focus on public opinion and/or congressional roll call votes as key variables of interest (see Adams 1997; Page et al. 1984; and Arceneaux 2002 as examples). Since this research is concerned with the behavior of state legislators, public opinion data are invalid for the dependent variable. At the same time, none of these previous works treated the question of elite polarization as a state-level analysis of Fiorina et al. (2006) findings. In addition, abortion-related interest groups, and even more general ideological organizations such as the ADA, either do not address state legislators, or do not keep scale-based scores for these legislators. One final option might be to use state House roll call votes. Yet this approach presents several additional concerns, not the least of which is a scarcity of enough floor votes on abortion legislation in the six states to create a valid and reliable scale. Hence, using interest group data at the state level means utilizing a dichotomous measurement for both reasonable theoretical and empirical reasons.

${ }^{5}$ NARAL computed state scores according to 14 categories of legal abortion restrictions. Higher scores are an indication of greater restrictions within the states through the year 2000. Since legislator abortion positions are recoded for the 2002-2003 election cycle, the 2001 NARAL data provide good measurement of the then-existing state abortion policy contexts.

${ }^{6}$ The breakdown of missing House members: 5 from Pennsylvania (4 men, 1 woman; 3 Republicans, 2 Democrats; representing 2.4\% of total state House members); 5 from Michigan (5 men; 4 Republicans, 1 Democrat; representing 4.5\% of total state House members); 4 from Ohio (3 men, 1 woman; 2 Republicans, 2 Democrats; representing @ 4\% of the total state House members); 3 from New York (3 men; 3 Democrats; representing $2 \%$ of total state House members); 3 from New Jersey ( 2 men, 1 woman; 2 Republicans, 1 Democrat; representing $3.5 \%$ of total state House members); 3 from Massachusetts (3 men; 3 Democrats; representing @ 2\% of total state House members). These Massachusetts members are omitted because interest groups report conflicting information on their abortion position. They are the only state House members omitted from all six states because for this reason.

${ }^{7}$ Given the prominence of former "pro-life" Pennsylvania Democratic Governor Robert P. Casey in the 1990s, and the emergence of his son, Robert Casey, Jr., who is also "pro-life," as the frontrunner in a U.S. Senate contest with prominent "pro-life" Republican Rick Santorum, the "pro-life" anomaly in Pennsylvania's Democratic Party appears to have significant historical roots in Keystone State politics. As an additional note, three of the five members for whom abortion position could not be found were Republican, thereby maintaining confidence in the breakdown on abortion position among Democratic House members in Pennsylvania. 


\section{REFERENCES}

Aldrich, John H. 1995. Why Parties? The Origin and Transformation of Political Parties in America. Chicago: The University of Chicago Press.

Ansolabehere, Stephen, James M. Snyder, Jr., and Charles Stewart III. 2001. Candidate Positioning in U.S. House Elections. American Journal of Political Science 45:136159.

Arceneaux, Kevin. 2002. Direct Democracy and the Link Between Public Opinion and State Abortion Policy. State Politics and Policy Quarterly 4: 372-387.

Arnold, R. Douglas. 1990. The Logic of Congressional Action. New Haven, CT: Yale University Press.

Burns, Gene. 1992. Commitments and Non-Commitments: The Social Radicalism of U.S. Catholic Bishops. Theory and Society 21:703-733.

Burns, Nancy, Kay Lehman Schlozman, and Sidney Verba. 2001. The Private Roots of Public Action: Gender, Equality, and Political Participation. Cambridge, MA: Harvard University Press.

Byrnes, Timothy. 1991. Catholic Bishops in American Politics. Princeton: Princeton University Press.

Byrnes, Timothy. 1993. The Politics of the American Catholic Hierarchy. Political Science Quarterly 108:497-515.

Carmines, Edward G., James A. Stimson. 1980. The Two Faces of Issue Voting. The American Political Science Review 74:78-91.

Castelli, Jim. 1987. A Tale of Two Cultures. Notre Dame Magazine 15:33-34.

Charles, Rodger. 1999. An Introduction to Catholic Social Teaching. San Francisco: Ignatius Press.

Cook, Elizabeth Adell, Ted G. Jelen, and Clyde Wilcox. 1993. State Political Cultures and Public Opinion about Abortion. Political Research Quarterly 46:771-781.

Dodd, Lawrence C. 1993. Congress and the Politics of Renewal: Redressing the Crisis of Legitimation. In Congress Reconsidered, 5th ed., eds. Lawrence C. Dodd and Bruce I. Oppenheimer. Washington, DC: CQ Press.

Erikson, Robert S., Gerald C. Wright, and John P. McIver. 1993. Statehouse Democracy: Public Opinion and Public Policy in the American States. Cambridge, UK: Cambridge University Press.

Fairbanks, David. 1977. Religious Forces and 'Morality' Policies in the American States. Western Political Quarterly 30:411-417.

Fenno, Richard, F. 1978. Home Sstyle: House Members in Their Districts. New York: Harper Collins.

Fischer, Claude S. 1995. The Subcultural Theory of Urbanism: A Twentieth-Year Assessment. The American Journal of Sociology 101:543-577.

Fiorina, Morris P., with Samuel J. Abrams and Jeremy C. Pope. 2006. Culture War? The Myth of a Polarized America, 2nd ed. New York: Pearson Longman.

Fowler, Paul B. 1987. Abortion: Toward an Evangelical Consensus. Portland, OR: Multnomah Press.

Gay, David, and John Lynxwiler. 1999. The Impact of Religiosity on Race Variations in Abortion Attitudes. Sociological Spectrum 19:359-378.

Glaser, James M. 1996. Race, Campaign Politics, and the Realignment in the South. New Haven, CT: Yale University Press. 
Green, John C. 2000. The Christian Right at the Millennium. American Jewish Committee Publications, New York City, http://www.ajc.org/InTheMedia/ Publications.asp?did=139

Green John C., and James L. Guth. 1991. Religion, Representatives, and Roll Calls. Legislative Studies Quarterly 16:571-584.

Green, John C., Mark J. Rozell, and Clyde Wilcox, eds. 2003. The Christian Right in American Politics: Marching to the Millennium. Washington, DC: Georgetown University Press.

Guth, James L., and John C. Green. 1991. An Ideology of Rights: Support for Civil Liberties among Political Activists. Political Behavior 13:321-344.

Guth, James L., John C. Green, Corwin E. Smidt, Lyman A. Kellstedt, and Margaret M. Poloma. 1997. The Bully Pulpit: The Politics of Protestant Clergy. Lawrence: University of Kansas Press.

Hall, Elaine J., and Myra Marx Ferree. 1986. Race Differences in Abortion Attitudes. Public Opinion Quarterly 50:193-207.

Hansen, Susan B. 1993. Differences in Public Policies toward Abortion: Electoral and Policy Context. In Understanding the New Politics of Abortion, ed. Malcolm L. Goggin. Newbury Park, CA: Sage.

Hunter, James Davison. 1991. Culture Wars: The Struggle to Define America. New York: Basic Books.

Jackson, John E., and John W. Kingdon. 1992. Ideology, Interest Group Scores, and Legislative Votes. American Journal of Political Science 36:805-823.

Jelen, Ted G. 2003. Catholic Priests and the Political Order: The Political Behavior of Catholic Pastors. Journal for the Scientific Study of Religion 42:591-604.

Jelen, Ted G. 2004. Roman Catholic Priests. In Pulpit and Politics: Clergy in American Politics at the Advent of the Millennium, ed. Corwin E. Smidt. Waco, TX: Baylor University Press.

Jones, Dale E., Sherri Doty, Clifford Grammich, James E. Horsch, Richard Houseal, Mac Lynn, John P. Marcum, Kenneth M. Sanchagrin, and Richard H. Taylor. 2002. Religious Congregations and Membership in the United States 2000: An Enumeration by Region, State and County Based on Data Reported for 149 Religious Bodies. Nashville, TN: Glenmary Research Center.

Kelley, Jonathan, M.D.R. Evans, and Bruce Headey. 1993. Moral Reasoning and Political Conflict: The Abortion Controversy. The British Journal of Sociology 44:589612.

Kellstedt, Lyman, and John C. Green. 1993. Knowing God's Many People. In Rediscovering the Religious Factor in American Politics, eds. David Leege and Lyman Kellstedt. Armonk, NY: Sharpe.

Leege, David C., and Michael R. Welch. 1989. Religious Roots and Political Orientations: Variations Among American Catholic Parishioners. Journal of Politics 51:137-162.

Leege, David C., Kenneth D. Wald, Brian S. Krueger, and Paul D. Mueller. 2002. The Politics of Cultural Differences: Social Change in the Post-New Deal Period. Princeton: Princeton University Press.

Mayhew, David R. 1974. Congress: The Electoral Connection. New Haven, CT: Yale University Press.

McCarthy, John D., and Mayer N. Zald. 1977. Resource Mobilization and Social Movements: A Partial Theory. American Journal of Sociology 82:1212-1241.

McMullen, Mike. 1994. Religious Polities as Institutions. Social Forces 73:709-728. 
Medoff, Marshall H. 2002. The Determinants and Impact of State Abortion Restrictions. American Journal of Economics and Sociology 61:481-493.

Meier, Kenneth, and Deborah McFarlane. 1993. The Politics of Funding Abortion: State Responses to the Political Environment. American Politics Quarterly 21:81-101.

Morris, Aldon. 1996. The Black Church in the Civil Rights Movement: The SCLC as a Decentralized, Radical Arm of the Black Church. In Disruptive Religion: The Force of Faith in Social Movement Activism, ed. Christian Smith. New York: Routledge.

National Abortion Rights Action League. 2001. Who Decides? A State-by-State Review of Abortion Rights. Washington, DC: National Abortion Rights Action League.

Norrander, Barbara, and Clyde Wilcox. 1999. Public Opinion and Policymaking in the States: The Case of Post-Roe Abortion Policy. Policy Studies Journal 27:707-722.

O'Connor, Karen. 1996. No Neutral Ground? Abortion Politics in an Age of Absolutes. Boulder, CO: Westview Press.

O'Connor, Robert, and Michael Berkman. 1995. Religious Determinants of State Abortion Policy. Social Science Quarterly 76:447-459.

Oldmixon, Elizabeth Anne. 2005. Uncompromising Positions: God, Sex, and the U.S. House of Representatives. Washington, DC: Georgetown University Press.

Olson, Laura R. 2000. Filled with Spirit and Power: Protestant Clergy in Politics. Albany: State University of New York Press.

Olson, Laura R., Sue E. S. Crawford, and Melissa M. Deckman. 2005. Women with a Mission: Religion, Gender, and the Politics of Women Clergy. Tuscaloosa: The University of Alabama Press.

Penning, James M. 1998. The Political Behavior of American Catholics: An Assessment of the Impact of Group Integration vs. Group Identification. The Western Political Quarterly 41:289-308.

Pew Hispanic Center and the Henry J. Kaiser Family Foundation. October 2002. National Survey of Latinos: The Latino Electorate. Washington, DC. www.pewhispanic.org.

Pew Forum on Religion and Public Life. August 2005. Abortion and Rights of Terror Suspects Top Court Issues. Washington, DC. http://pewforum.org.

Rabinowitz, George and Stuart Elaine MacDonald. 1989. A Directional Theory of Issue Voting. American Political Science Review 83:93-121.

Regnerus, Mark D., David Sikkink, and Christian Smith. 1999. Voting with the Christian Right: Contextual and Individual Patterns of Electoral Influence. Social Forces 77: 1375-1401.

Roche, Douglas. 1970. The Challenge to Authority in the Catholic Church. In American Mosaic: Social Patterns of Religion in the United States, eds. Phillip E. Hammond and Benton Johnson. New York: Random House.

Rohde, David W. 1991. Parties and Leaders in the Postreform House. Chicago: University of Chicago Press.

Rozell, Mark J., and Clyde Wilcox, eds. 1995. God at the Grass Roots: The Christian Right in the 1994 Elections. Lanham, MD: Rowman \& Littlefield Publishers.

Sharp, Elaine B., ed. 1999. Culture Wars and Local Politics. Lawrence: University of Kansas Press.

Smidt, Corwin, ed. 2004. Pulpit and Politics: Clergy in American Politics at the Advent of the Millennium. Waco, TX: Baylor University Press.

Tatalovich, Raymond, and David Schier. 1993. The Persistence of Ideological Cleavage in Voting on Abortion Legislation in the House of Representatives, 1973-1988. American Politics Quarterly 21:125-139. 
148 | Brian Robert Calfano

Wald, Kenneth D. 2003. Religion and Politics in the United States, 4th ed. Lanham, MD: Rowman and Littlefield.

Wald, Kenneth D., Dennis E. Owen, and Samuel S. Hill, Jr. 1988. Churches as Political Communities. American Political Science Review 82:531-548.

Wetstein, Matthew E., and Robert B. Albritton. 1995. Effects of Public Opinion on Abortion Policies and Use in the American States. Publius: The Journal of Federalism 25:91-105.

Zeitlin, Irving M. 2003. The Religious Experience: Classical Philosophical and Social Theories. New York: Prentice Hall. 